\title{
Community structure of bathyal decapod crustaceans off south-west Balearic Islands (western Mediterranean): seasonality and regional patterns in zonation
}

\author{
Francesc Maynou* and Joan E. Cartes \\ Institut de Ciències del Mar, CSIC, PgJoan de Borbó s/n, 08039-Barcelona, Spain. *E-mail: maynouf@icm.csic.es
}

\begin{abstract}
The community structure of decapod crustacean assemblages was established and analysed from two experimental trawl samplings. The data were taken in the south-west Balearic Islands (Algerian Basin, western Mediterranean Sea) at depths ranging from $\sim 200$ to $1800 \mathrm{~m}$. The results of multivariate analysis indicate that the community structure remained constant between samplings. The analysis also revealed that there exist differences between bathyal decapod communities at a regional level $(<1000 \mathrm{~km})$ when compared with well-studied nearby areas. The differences relate mainly to the relative contribution of different species and feeding guilds, not to the taxonomic composition of the assemblages studied. It is proposed that these differences result from contrasting surface production regimes (coastal vs open sea) and food web organization (relative dependence on mesopelagic or infaunal prey).
\end{abstract}

\section{INTRODUCTION}

During the last decades, the organization of deep-sea megafaunal communities has been intensively studied (Rowe \& Menzies, 1969; Haedrich et al., 1975, 1980; Smith \& Hamilton, 1983; Abelló et al., 1988; Markle et al., 1988; Cartes \& Sardà, 1993; Stefanescu et al., 1992). Fish were the focus of most of these studies, probably due to their dominance in terms of biomass in deep-sea communities from mid latitudes and because they are subject to a growing interest related to the development of new fisheries and fishing grounds (Merrett \& Haedrich, 1997). The results of these studies have permitted the establishment of the biomass and diversity distribution patterns and the boundaries between communities (zonation).

Trophic arguments have variously been used to explain community organization at different spatial and temporal scales (Dayton \& Hessler, 1972; Gage \& Tyler, 1991), and to explain changes in megafaunal/macrofaunal community structure, although only a few studies relate changes in megafaunal/macrofaunal community structure with changes in food supply (from superficial phytoplankton pigment concentration to faunal diets; Watts et al., 1992). At a coarse scale, seasonally averaged phytoplankton pigment concentration can be a useful index of the magnitude or organic vertical flux and food supply for demersal megafauna (Rex et al., 1993).

A limited number of studies on decapod crustacean assemblages exist (Wenner \& Boesch, 1979; Abelló et al., 1988; Cartes \& Sardà, 1993), although this taxon is less well documented than fish. Decapod crustaceans are a dominant or subdominant faunal component in subtemperate to subtropical assemblages, such as the Mediterranean Sea, and are a key taxon linking lower and higher trophic levels (Cartes, 1998). Therefore, studies on the organization of dominant megafaunal taxa other than fish, with different trophic requirements, can offer a new approach to the study of megafaunal community structure and function.

More or less clearly separated communities have been described for megafaunal assemblages at bathyal and abyssal depths, but somewhat conflicting conclusions can be drawn from these results: first, although the geographic variation is important, most results point to a recurring boundary between the upper and middle slope assemblages, located at 300-700 m (Day \& Pearcy, 1968; Haedrich et al., 1975, 1980). In the deep Mediterranean Sea, this boundary was established at comparable depths (between 350 and $500 \mathrm{~m}$ ) by Abelló et al. (1988) and Cartes et al. (1994) for decapods of the Catalan Sea. The boundary between the middle and the lower slope assemblages was established at depths ranging between 1000-1400 m (Day \& Pearcy, 1968; Haedrich et al., 1975; 1980; Wenner \& Boesch, 1979; Hecker, 1990), with little variation between fish and decapod crustaceans in the deep western Mediterranean (Cartes \& Sardà, 1993; Stefanescu et al., 1992; Moranta et al., 1998).

On the other hand, the boundaries between communities seem to be weaker at low latitudes (Gage \& Tyler, 1991) and, in many cases, zonation seems to be more of a regional than a general phenomenon, of only local significance. As pointed out by Haedrich \& Merrett (1990) for Atlantic deep-sea fish assemblages, it is problematic to extrapolate a locally observed trend to wider geographic areas. These seemingly conflicting views (existence of boundaries at recurring depth zones and local significance of deep-sea assemblages) can perhaps be reconciled by looking into the abiotic and biotic factors governing species distributions and biogeographic aspects but also considering the differences in practical and methodological aspects (such as sampling intensity).

The objectives of the present work are to present new results on community organization of deep-water decapods in the south-west Balearic Islands, to compare the 
results with the well-studied Catalan Sea (located $\sim 300 \mathrm{~km}$ to the north of the Balearic Islands) and, drawing from this comparison, to investigate the underlying factors structuring local communities of deep-water megafauna. We discuss the relevance of ecological (especially, trophic and environmental factors) and biogeographical aspects in structuring deep-water communities. We especially invoke trophic arguments to explain some patterns, bearing in mind the particular environmental conditions of the deep Mediterranean, with thermal and saline stability, below 200 m (Fredj \& Laubier, 1985).

\section{MATERIALS AND METHODS}

\section{Data source}

Two oceanographic cruises were conducted in 1996 (Q1, October) and 1998 (Q2, May), in the Algerian Basin south-west of the Balearic Islands (western Mediterranean; Figure 1) to study the bottom-living community on the continental slope, for two contrasting oceanographic conditions. The megafaunal assemblage (comprising mostly fish and decapod crustaceans) was sampled by means of an experimental trawl MST, equipped with two doors, a single trawl warp, and a $25-\mathrm{m}$ long bridle. The general size and structure of the trawl is close to the OTSB-14 commonly used in deep sea megafaunal studies (Merrett \& Marshall, 1981). Forty-five valid bottom trawls were performed (31 during Q1 and 14 during Q2; Table 1). The trawl hauls lasted for $0.5 \mathrm{~h}$ (effective trawling time) and were monitored by means of an acoustic device (SCANMAR). Megafaunal species were determined to specific level (in Table 2 the list of decapods collected is included), counted and weighed ( $g$ wet weight). The exact area swept by the trawl was quantified with the SCANMAR readings, and was used to compute the abundance (number and weight) of the catch $10,000 \mathrm{~m}^{-2}$. A CTD probe was used to determine the environmental characteristics of the water column (temperature, salinity and fluorescence). The CTD casts were performed along a transect for each oceanographic cruise, using a Seabird 25 probe with an attached Seatech flurometer.

\section{Statistical analyses}

The data on megafaunal abundance were plotted over a depth axis to display the trends with depth of the standardized abundance indices (N $10,000 \mathrm{~m}^{-2}$ and g $10,000 \mathrm{~m}^{-2}$ ) for decapods and total megafauna. The identification of the main decapod crustacean assemblages was performed by multidimensional scaling (MDS) on the correlation matrix of the standardized abundance (N 10,000 $\mathrm{m}^{-2}$ ) for each trawl haul and for each sampling cruise. Species appearing less than three times on each cruise were not taken into consideration for further analysis. The similarity index used in MDS ordination was Pearson's product moment correlation $(r)$. The decapod assemblages (sensu Paine, 1994, table 1) identified were characterized by the following descriptors: mean density of the species comprising $95 \%$ of the abundance, species richness $(\mathrm{S})$, expected species number $(\mathrm{ES}(\mathrm{n})$; Hurlbert, 1971), relative contribution of feeding guilds (sensu Paine, 1994, table 1) and relative location in the water column. Following the feeding studies of Cartes (1998) for the same species in the nearby Catalan Sea, the decapod species studied were classified as migrator macroplankton-feeders (MMF), non-migrator macroplankton-feeders (NMF), macroplankton-feeders and scavengers (MSF), epifauna-feeders (EPI), infauna-feeders (INF) and deposit-feeders (DEF). Regarding their relative location in the water column, decapod crustaceans can be classified as mesopelagic species (undertaking day/night migrations in the water column), nektobenthic species (swimming or hovering above the sea bottom) and benthic species (living on or in the sea bottom, mostly corresponding to reptantian decapods). The ecological

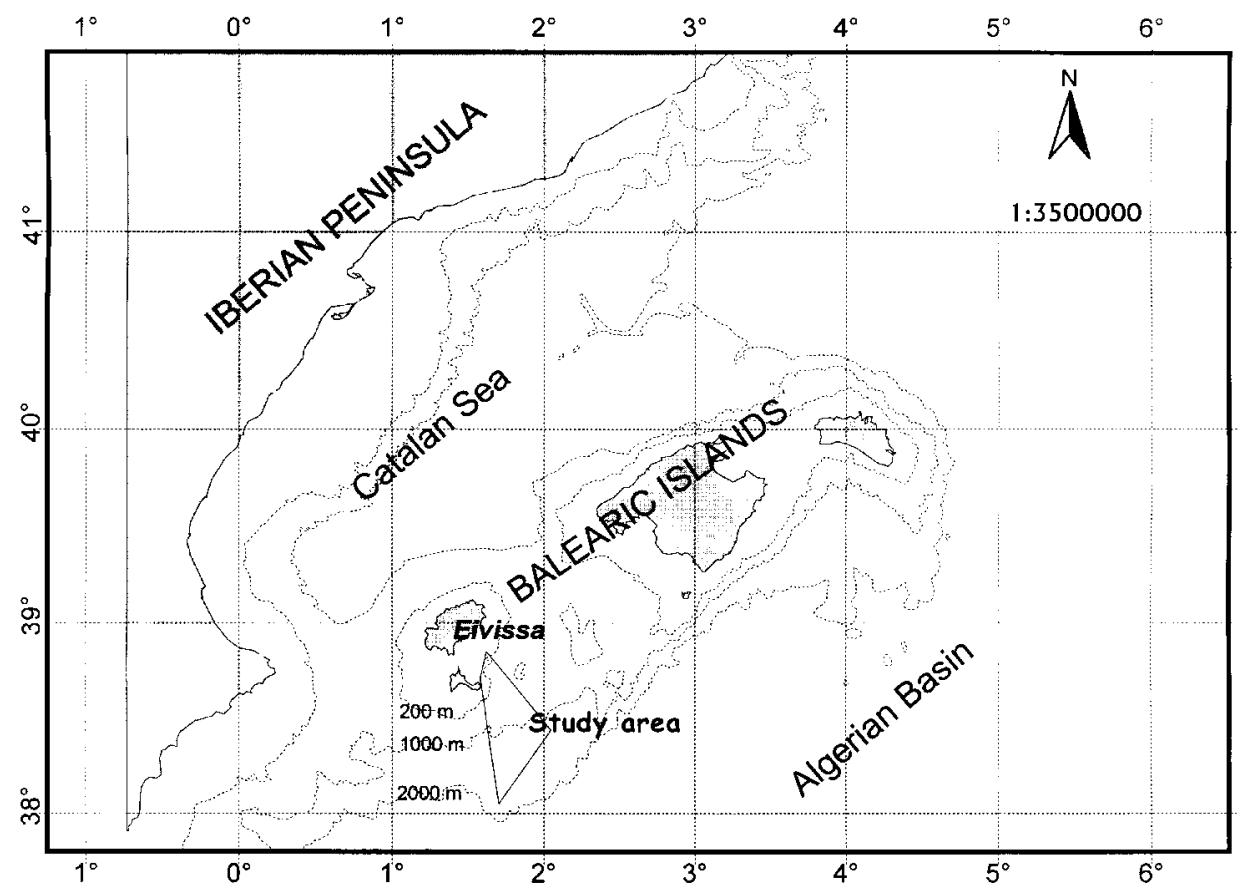

Figure 1. Location of the study area in the western Mediterranean Sea. 
Table 1. Depth distribution of trawl hauls. Cruise Q1, October 1996; cruise Q2, May 1998.

\begin{tabular}{rrr}
\hline Depth range $(\mathrm{m})$ & Cruise Q1 & Cruise Q2 \\
\hline $0-200$ & 0 & 1 \\
$200-400$ & 5 & 1 \\
$400-600$ & 4 & 2 \\
$600-800$ & 3 & 2 \\
$800-1000$ & 4 & 2 \\
$1000-1200$ & 4 & 2 \\
$1200-1400$ & 3 & 1 \\
$1400-1600$ & 6 & 2 \\
$1600-1800$ & 2 & 1 \\
Total & 31 & 14 \\
\hline
\end{tabular}

descriptors were analysed by season, comparing our two cruises and also, to enlarge the comparative value of the present study, we draw from published results (Cartes \& Sardà, 1993; Cartes et al., 1994) and own data from the well-studied, nearby area of the Catalan Sea, standardizing density values per unit area of $10,000 \mathrm{~m}^{2}$. Comparisons between the Catalan Sea and the south-west Balearic Islands were made at the levels of abundance/ biomass for the entire assemblage and for selected (indicator) species, faunal composition, and trophic groups (or guilds).

\section{RESULTS}

\section{Environmental features}

The thermal and saline stability reported for the deep Mediterranean Sea (Fredj \& Laubier, 1985) was confirmed by the CTD casts. Temperature varied between 13.0 and $13.5^{\circ} \mathrm{C}$ and salinity between 38.3 and $38.5 \mathrm{psu}$, from $200 \mathrm{~m}$ to the bottom at all localities sampled. On the continental slope, the muddy sediment comprises biogenic material (such as the foraminiferan Orbulina universa) of planktonic origin (Emelyanov, 1972). This type of sediment is indicative of oligotrophic conditions (Sokolova, 1972). The hydrological data recorded in the October 1996 cruise showed that the water masses were still structured as in the summer period, with a surface temperature of $21^{\circ} \mathrm{C}$ and a strong gradient between 50 and $100 \mathrm{~m}$ depth to $\sim 13.0^{\circ} \mathrm{C}$. During May 1998 , the surface temperature was $17.5^{\circ} \mathrm{C}$ and thermal stability was reached at around $200 \mathrm{~m}$ depth, with a less pronounced temperature gradient between 0 and $150 \mathrm{~m}$. This hydrological situation is indicative of early spring oceanographic conditions, with an incipient thermocline.

\section{Depth profiles}

In both cruises, a general decrease in crustacean decapod abundance (in number) was observed from 200 to $800 \mathrm{~m}$ (Figure 2, left), from over 100 ind $10,000 \mathrm{~m}^{-2}$ to about 20 ind $10,000 \mathrm{~m}^{-2}$. Their abundance slightly increased again beyond $1400 \mathrm{~m}$, to $\sim 70$ ind $10,000 \mathrm{~m}^{-2}$. Decapod abundance (in weight; Figure 2, middle) peaked to $1,000 \mathrm{~g} 10,000 \mathrm{~m}^{-2}$ between 600 and $800 \mathrm{~m}$ in both cruises, and decreased progressively afterwards. The
Table 2. Bathyal decapod crustaceans collected during cruises Q1 (October 1996) and Q2 (May 1998) off south-west Balearic Islands (Algerian Basin, western Mediterranean) in 44 valid trawl hauls from $\sim 200-1800 \mathrm{~m}$ depth.

\begin{tabular}{|c|c|c|c|}
\hline Family & Species & Occurrences & $\begin{array}{l}\text { Fre- } \\
\text { quency } \\
(\%)\end{array}$ \\
\hline \multirow{3}{*}{ Aristeidae } & Aristaeomorpha foliacea & 3 & 6.82 \\
\hline & Aristeus antennatus & 36 & 81.82 \\
\hline & Gennadas elegans & 20 & 45.45 \\
\hline \multirow[t]{2}{*}{ Peneaeidae } & Parapenaeus longirostris & 8 & 18.18 \\
\hline & Funchaliawoodwardii & 2 & 4.55 \\
\hline \multirow[t]{2}{*}{ Solenoceridae } & Solenocera membranacea & 9 & 20.45 \\
\hline & Hymenopenaeus debilis & 1 & 2.27 \\
\hline \multirow[t]{3}{*}{ Sergestidae } & Sergestes arcticus & 19 & 43.18 \\
\hline & Sergestes henseni & 6 & 13.64 \\
\hline & Sergia robusta & 33 & 75.00 \\
\hline Stenopodidae & Richardina fredericii & 5 & 11.36 \\
\hline \multirow[t]{2}{*}{ Oplophoridae } & Acanthephyra eximia & 23 & 52.27 \\
\hline & Acanthephyra pelagica & 24 & 54.55 \\
\hline \multirow[t]{2}{*}{ Pasiphaeidae } & Pasiphaea multidentata & 19 & 43.18 \\
\hline & Pasiphaea sivado & 5 & 11.36 \\
\hline Nematocarcinidae & Nematocarcinus exilis & 16 & 36.36 \\
\hline Alpheidae & Alpheus glaber & 5 & 11.36 \\
\hline Hippolitidae & Ligur ensiferus & 1 & 2.27 \\
\hline \multirow{2}{*}{ Processidae } & Processa canaliculata & 7 & 15.91 \\
\hline & Processa nouveli & 8 & 18.18 \\
\hline \multirow[t]{9}{*}{ Pandalidae } & Chlorotocus crassicornis & 6 & 13.64 \\
\hline & Pandalina profunda & 4 & 9.09 \\
\hline & Plesionika acanthonotus & 24 & 54.55 \\
\hline & Plesionika antigai & 5 & 11.36 \\
\hline & Plesionika edwardsi & 5 & 11.36 \\
\hline & Plesionika gigliolii & 8 & 18.18 \\
\hline & Plesionika heterocarpus & 12 & 27.27 \\
\hline & Plesionika martia & 13 & 29.55 \\
\hline & Plesionika narval & 2 & 4.55 \\
\hline \multirow{3}{*}{ Crangonidae } & Philocheras echinulatus & 3 & 6.82 \\
\hline & Pontocaris lacazei & 5 & 11.36 \\
\hline & Pontophilus norvegicus & 12 & 27.27 \\
\hline Nephropidae & Nephrops norvegicus & 7 & 15.91 \\
\hline Axiidae & Calocaris macandreae & 9 & 20.45 \\
\hline \multirow[t]{2}{*}{ Polychelidae } & Polycheles typhlops & 24 & 54.55 \\
\hline & Stereomastis sculpta & 17 & 38.64 \\
\hline Diogenidae & Dardanus arrosor & 1 & 2.27 \\
\hline \multirow[t]{3}{*}{ Galatheidae } & Munida intermedia & 4 & 9.09 \\
\hline & Munida iris & 7 & 15.91 \\
\hline & Munida tenuimana & 27 & 61.36 \\
\hline Homolidae & Paromola cuvieri & 12 & 27.27 \\
\hline \multirow[t]{2}{*}{ Majidae } & Dorhynchus thomsoni & 3 & 6.82 \\
\hline & Macropodia longipes & 7 & 15.91 \\
\hline Geryonidae & Geryon longipes & 25 & 56.82 \\
\hline \multirow[t]{2}{*}{ Portunidae } & Macropipus tuberculatus & 8 & 18.18 \\
\hline & Bathynectes maravigna & 1 & 2.27 \\
\hline Goneplacidae & Goneplax rhomboides & 4 & 9.09 \\
\hline Xanthidae & Monodaeus couchi & 4 & 9.09 \\
\hline
\end{tabular}

megafaunal abundance depth profile (Figure 2, left) was markedly influenced by fish biomass, decreasing very rapidly from 1,000 ind $10,000 \mathrm{~m}^{-2}$ at $200 \mathrm{~m}$ (shelf break) to about 100 ind $10,000 \mathrm{~m}^{-2}$ at $800 \mathrm{~m}$. The megafaunal depth profile stabilized below this depth at $\sim 60$ ind $10,000 \mathrm{~m}^{-2}$, with a secondary peak higher than 100 ind $10,000 \mathrm{~m}^{-2}$ at $1400-1600 \mathrm{~m}$ depth. This secondary peak in abundance resulted from the high abundance of the 
A
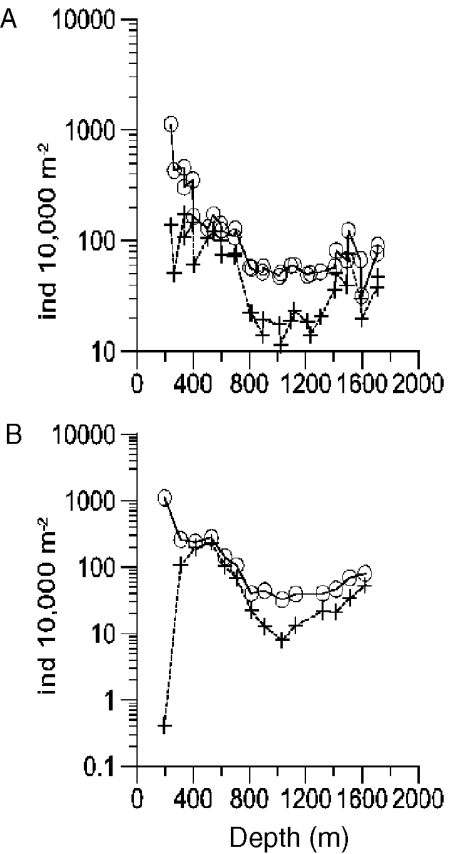
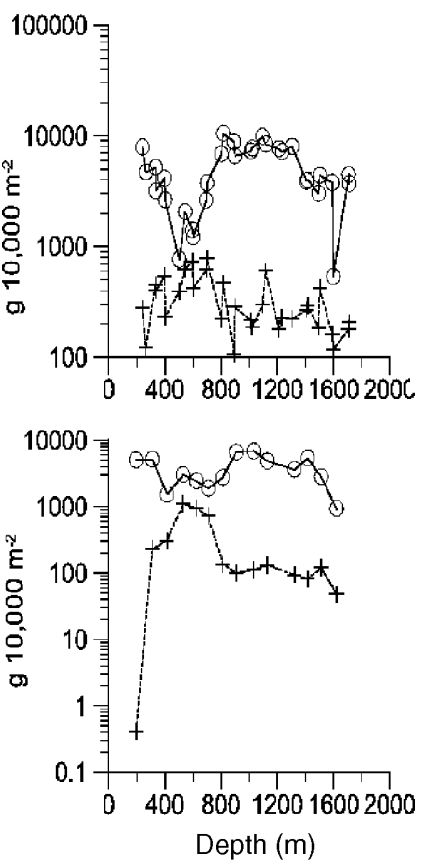
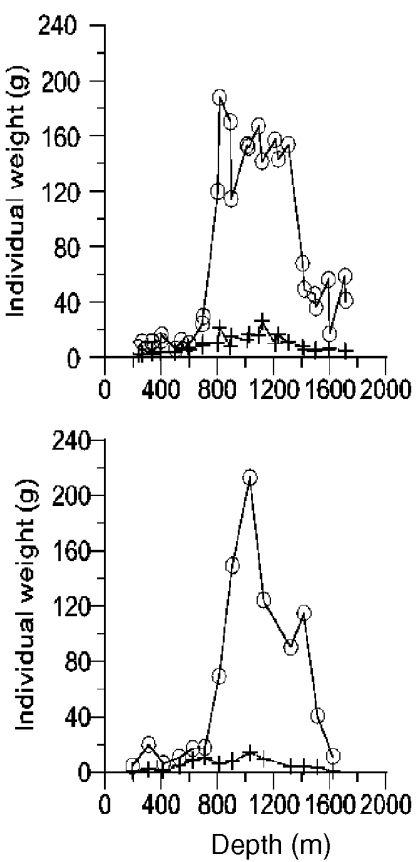

Figure 2. Distribution by depth of the abundance (number and weight $10,000 \mathrm{~m}^{-2}$ ) and individual weight of decapod crustaceans (crosses and hatched lines) and total megafauna (circles and solid lines). (A) Cruise Q1 (October 1996); (B) cruise Q2 (May 1998).

deep-sea fish Alepocephalus rostratus (cf. Moranta et al., 1998). In terms of biomass (Figure 2, middle), the pattern changed completely: megafaunal biomass decreased rapidly from $10,000 \mathrm{~g} 10,000 \mathrm{~m}^{-2}$ at $200 \mathrm{~m}$ to $1,000 \mathrm{~g}$ $10,000 \mathrm{~m}^{-2}$ at $400 \mathrm{~m}$, but increased again rapidly to reach values of $\sim 10,000 \mathrm{~g} 10,000 \mathrm{~m}^{-2}$ between 800 and $1200 \mathrm{~m}$. These high megafaunal densities were comparable to the biomass densities at the shelf break. This secondary peak in megafaunal biomass (at 800-1200 m) has been previously reported for fishes in the Mediterranean (Stefanescu et al., 1992) and can be attributed to high individual weight for fish, and to a lesser extent decapod crustaceans, at these depths (Figure 2, right). It is interesting to note that decapod crustaceans accounted for a large share of the megafaunal abundance at $\sim 400-800 \mathrm{~m}$, for both cruises, totalling 70 and $40 \%$ of the megafaunal density in number and weight, respectively. To a lesser extent, decapods again became important, but only in number below $1400 \mathrm{~m}$.

\section{Results of MDS analysis}

The results of the multidimensional scaling analysis are shown in Figure 3. Three clearly differentiated groups emerged in the first cruise: a shelf break/upper slope assemblage (SST/US) comprising trawl hauls between 230 and $404 \mathrm{~m}$ depth, a shallow middle-slope assemblage (MS1, 544-602 m depth) and a deep middle-slope to lower slope assemblage (MS2, 687-1714 m). In the second cruise, the same three groups were found although at slightly different depths. The SST/US assemblage comprised hauls from 195 to $312 \mathrm{~m}$, the MS1 assemblage from 415 to $529 \mathrm{~m}$ and the MS2 assemblage from 626 to $1622 \mathrm{~m}$. The first two dimensions of the MDS were plotted against depth and species richness (Figure 4). The first dimension of the MDS ordination was explained by the depth gradient at least down to $800 \mathrm{~m}$ (corresponding approximately to the SST/US and MS1 assemblages), while the second dimension was correlated with species richness, for both surveys.

\section{Community characteristics}

The summary features of the decapod assemblages studied are reported in Table 3. In Q1, species richness was higher than in Q2 but this is probably an artefact resulting from the paucity of samples in the second survey and the area-diversity relationship. High abundance (more than 100 ind $10,000 \mathrm{~m}^{-2}$ ) of crustacean decapods was found on the SST/US and the MS1 assemblages, for both surveys. The abundance then diminished deeper, on the MS2 assemblage (below $600 \mathrm{~m}$ ), to 36 ind 10,000 $\mathrm{m}^{-2}$. On the other hand, the abundance in weight showed values of more than $500 \mathrm{~g} 10,000 \mathrm{~m}^{-2}$ on the MS1 assemblage, while decapod biomass was half this value both in shallower and deeper waters. No marked seasonal differences were recorded between Q1 (October 1996) and Q2 (May 1998) in abundance or biomass for each assemblage (Table 3). Only in the MSl assemblage an increase in density (in number as well as biomass) can be detected, from $\sim 100$ ind $10,000 \mathrm{~m}^{-2}$ in $\mathrm{Q} 1$ to over 200 ind $10,000 \mathrm{~m}^{-2}$ in $\mathrm{Q} 2$, and a slight increase in biomass, from

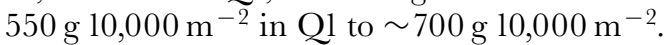

The decapod crustacean assemblages identified by the multivariate analysis can be characterized as follows (Tables 4 \& 5): in Q1, the SST/US assemblage comprised a relatively large number of species $(S=25)$, but $95 \%$ of the abundance was accounted for by only six species. This assemblage was clearly dominated by the pandalid shrimps of the genus Plesionika, chiefly P. heterocarpus and P. edwardsi (accounting for $85.7 \%$ of abundance in number and $74.4 \%$ of abundance in weight; Table 4 ). 

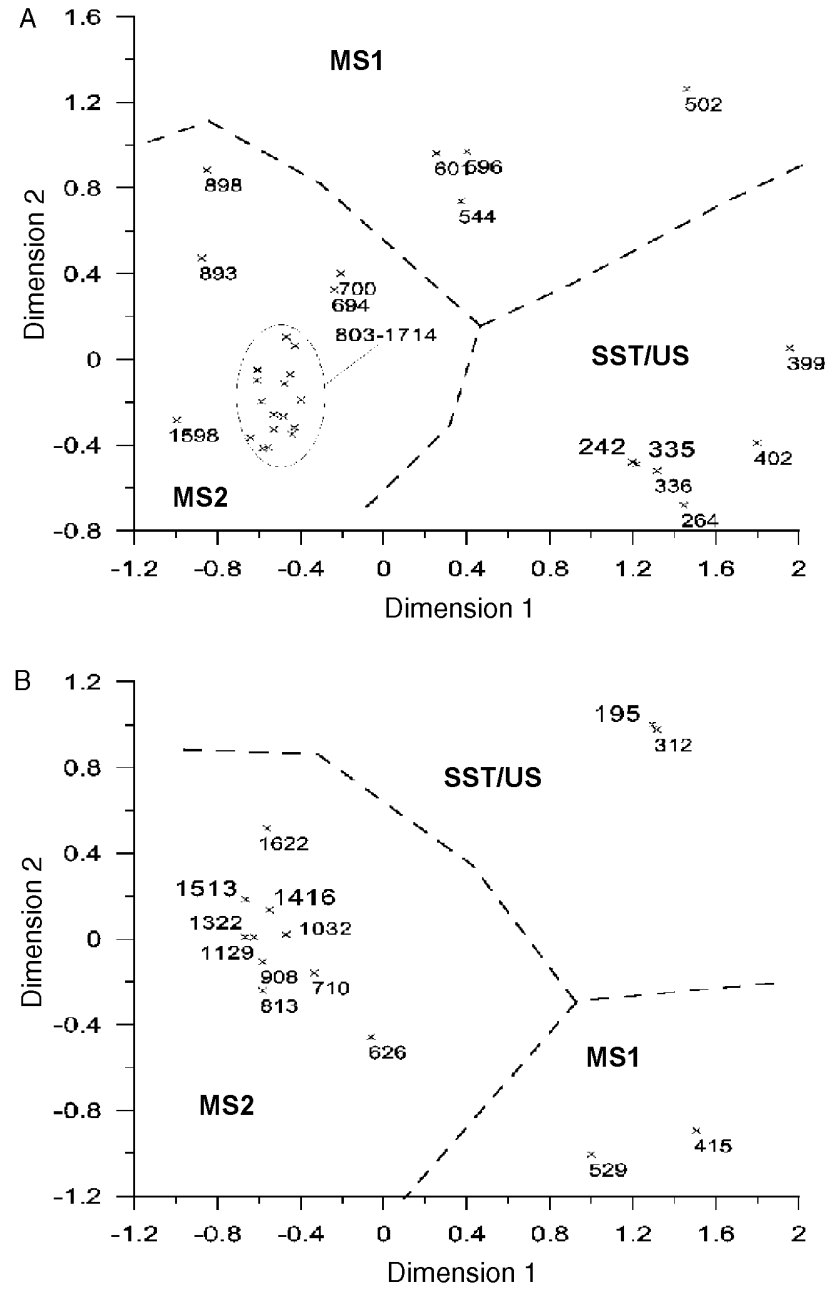

Figure 3. Multidimensional scaling ordination of decapod crustacean samples in (A) cruise Q1 (October 1996, stress of MDS ordination: 0.075); and (B) cruise Q2 (May 1998, stress of MDS ordination: 0.026).

In the MSl assemblage, nektobenthic decapods clearly dominated the species composition (making up $75 \%$ of the abundance in number and weight), consisting of pandalids (P. martia, P. acanthonotus and $P$. gigliolii) and the aristeid Aristeus antennatus. In this assemblage, the species richness was higher $(\mathrm{S}=28)$ and mesopelagic (Sergestes arcticus, Pasiphaea sivado) and benthic (Processa spp., Solenocera membranacea, Philocheras echinulatus, Munida tenuimana, Calocaris macandreae, Nephrops norvegicus) species became important. In the MS2 assemblage, species richness was relatively high $(S=27)$ and typical bathyal species became dominant, such as Acanthephyra spp. and Nematocarcinus exilis, although the species reaching the highest density were the shrimps $A$. antennatus and Plesionika martia. It is noteworthy that the deep-sea red crab Geryon longipes represented 20.5\% of the decapod biomass, although it was not very abundant in number.

In the survey Q2, the dominance of Plesionika heterocarpus over the SST/US assemblage was also clear (78\% of abundance in number, $47.2 \%$ in biomass) and species richness was very low, with only three species accounting for $95 \%$ of the abundance. In the MS1 assemblage, the species composition was similar to the composition reported for Q1, but their relative dominance differed. In Q2, the dominant species was Plesionika
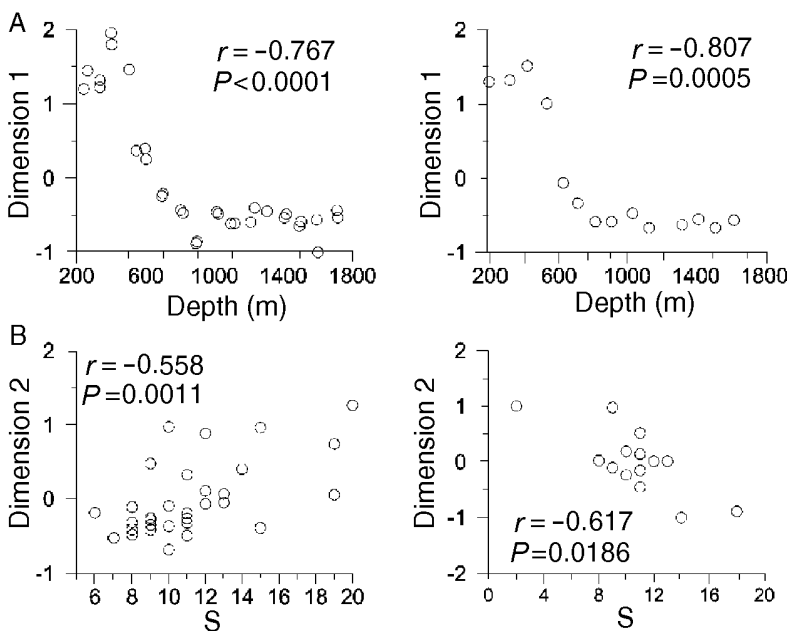

Figure 4. Plot of the first and second dimensions resulting from the MDS ordination vs depth (A) and species richness (B) for cruises Q1 (left) and Q2 (right). Inset in each graph: results of Spearman's rank correlation $(r)$ and associated probability.

Table 3. Depth distribution, diversity and abundance (mean number and mean weight $10,000 \mathrm{~m}^{-2} \pm S D$ ) of decapod crustacean assemblages classified by $M D S$.

\begin{tabular}{|c|c|c|c|c|c|}
\hline Cruise & Assemblage & $\begin{array}{l}\text { Depth range } \\
(\mathrm{m})\end{array}$ & $\mathrm{S}$ & Ind & Weight \\
\hline \multirow[t]{3}{*}{ Q1 } & SST/US & 242-402 & 25 & $114.2 \pm 15.2$ & $340 \pm 37$ \\
\hline & MS1 & $502-601$ & 28 & $101.8 \pm 4.2$ & $550 \pm 70$ \\
\hline & MS2 & $694-1714$ & 27 & $32.8 \pm 5.2$ & $298 \pm 31$ \\
\hline \multirow[t]{3}{*}{ Q2 } & $\mathrm{SST} / \mathrm{US}$ & $195-312$ & 9 & $107.8 \pm 31.2$ & $229 \pm 49$ \\
\hline & MS1 & $415-529$ & 23 & $217.3 \pm 17.3$ & $709 \pm 59$ \\
\hline & MS2 & $626-1622$ & 23 & $36.0 \pm 3.4$ & $249 \pm 12$ \\
\hline
\end{tabular}

gigliolii (cf. with P. martia in Q1) and the mesopelagic Sergestes arcticus became very important $(21.4 \%$ in number although only $1.0 \%$ in weight due to its small size). Aristeus antennatus diminished in abundance compared with the first survey, while Nephrops norvegicus and P. edwardsii became more abundant. In the MS2 assemblage, both species composition and relative dominance remained constant between surveys, e.g. A. antennatus and P. martia were the dominant species in both surveys accounting for most of the abundance, while other typical bathyal species came next in abundance.

Regarding their relative distribution on or above the sea-floor, the crustacean decapods could be characterized as mostly nektobenthic during both cruises in the SST/US assemblage (more than $90 \%$ of the abundance in number or weight; Tables $4 \& 5$ ). In the MS1 assemblage, nektobenthic species still made up more than $50 \%$ of the abundance, but benthic decapods became significant and, to a lesser extent and for cruise Q2 only, mesopelagic decapods also. In the MS2 assemblage, nektobenthic species dominate again, with around $80 \%$ of the abundance in each cruise and benthic and mesopelagic species have a small representation. Note, however, that the occasional presence of large-bodied species such as the red crab Geryon longipes can contribute significantly to the dominance of benthic species in biomass. 
Table 4. Abundance (number and weight 10,000 $\mathrm{m}^{-2}$, and percentages of total) of decapod crustacean species accounting for more than $95 \%$ of abundance in number, for cruise Q1.

\begin{tabular}{|c|c|c|c|c|}
\hline Species/assemblage & Ind & $\%$ & Weight & $\%$ \\
\hline \multicolumn{5}{|l|}{ A. SST/US } \\
\hline Plesionika heterocarpus $^{\dagger}$ & 76.2 & 44.9 & 155 & 28 \\
\hline Plesionika edwardsi ${ }^{\dagger}$ & 49.4 & 29.1 & 220 & 40. \\
\hline Plesionika gigliolii $^{\dagger}$ & 14.7 & 8.6 & 26 & \\
\hline Parapenaeus longirostris ${ }^{\dagger}$ & 10.8 & 6.4 & 105 & 19 \\
\hline Plesionika antigai ${ }^{\dagger}$ & 5.3 & 3.1 & 6 & 1. \\
\hline Munidairis & 2.7 & 1.6 & 11 & 2.1 \\
\hline \multicolumn{5}{|l|}{ B. MS1 } \\
\hline Plesionika martia $^{\dagger}$ & 43.9 & 36.3 & 234 & 33. \\
\hline Plesionika gigliolii ${ }^{\dagger}$ & 19.3 & 15.9 & 44 & \\
\hline Aristeus antennatus $^{\dagger}$ & 15.7 & 13.0 & 189 & 27. \\
\hline Plesionika acanthonotus ${ }^{\dagger}$ & 10.9 & 9.0 & 20 & \\
\hline Pasiphaea sivado* & 4.6 & 3.8 & 7.2 & 1. \\
\hline Sergestes arcticus* & 4.5 & 3.7 & 1 & $<1.0$ \\
\hline Munida tenuimana & 3.5 & 2.9 & 24 & 3.5 \\
\hline Solenocera membranacea & 2.6 & 2.1 & 6 & $<1.0$ \\
\hline Munida intermedia & 2.4 & 2.0 & 12 & 1.7 \\
\hline Calocaris macandreae & 2.3 & 1.9 & 1 & $<1$ \\
\hline Nephrops norvegicus & 1.8 & 1.5 & 59 & \\
\hline \multicolumn{5}{|l|}{ C. MS2 } \\
\hline Aristeus antennatus $^{\dagger}$ & 15.2 & 30.9 & 113 & 24 \\
\hline Plesionika martia ${ }^{\dagger}$ & 11.0 & 22.4 & 80 & 17 \\
\hline Acanthephyra eximia ${ }^{\dagger}$ & 6.6 & 13.4 & 40 & \\
\hline Plesionika acanthonotus ${ }^{\dagger}$ & 3.2 & 6.5 & 4 & $<1$ \\
\hline Sergia robusta* & 2.3 & 4.6 & 3 & $<1$ \\
\hline $\mathcal{N e m a t o c a r c i n u s ~ e x i l i s ~}^{\dagger}$ & 2.1 & 4.2 & 2 & $<1$ \\
\hline Munida tenuimana & 1.6 & 3.3 & 4 & $<1$ \\
\hline Gennadas elegans* & 1.3 & 2.6 & $<1$ & $<1.0$ \\
\hline Geryon longipes & 0.8 & 1.9 & 95 & 20.5 \\
\hline Pasiphaea multidentata* & 0.9 & 1.8 & 3 & $<1.0$ \\
\hline Polycheles typhlops & 0.8 & 1.7 & 6 & 1. \\
\hline Acanthephyra pelagica* & 0.7 & 1.5 & 4 & $<1.0$ \\
\hline
\end{tabular}

*, mesopelagic species; ${ }^{\dagger}$, nektobenthic species. All other species are benthic.

Regarding the food habits of the species studied, nonmigrating macroplankton feeders (NMF; Figure 5) made up $50 \%$ or more of the decapod crustacean biomass, at all depths sampled, except for the MS2 assemblage in Q1 (October 1996). The contribution of other feeding strategies varied across depths and between cruises: Thus, decapods feeding on infaunal prey (INF; Figure 5) were also important in all assemblages and for the two cruises. On the lowest depth assemblage, MS2, the contribution of epifaunal feeders to the total biomass became very important.

\section{Biogeographical aspects}

The expected number of species, ES(n), shows that the MSl assemblage was the more diverse, followed by the MS2 (Figure 6). The appearance of new, typical deep-sea species contributed to the high diversity of MS2 but it did not suffice to offset the loss of species with depth. Regarding the species composition, the faunistic assemblages reported here represent all species previously reported for the Catalan Sea (excluding Hymenopenaus debilis, firstly reported for Mediterranean waters in our samplings; Cartes et al., 2000). Differences
Table 5. Abundance (number and weight 10,000 $\mathrm{m}^{-2}$, and percentages of total) of decapod crustacean species accounting for more than $95 \%$ of abundance in number, for cruise Q2.

\begin{tabular}{|c|c|c|c|c|}
\hline Species/assemblage & Ind & $\%$ & Weight & $\%$ \\
\hline \multicolumn{5}{|l|}{ A. SST/US } \\
\hline Plesionika heterocarpus $^{\dagger}$ & 47.8 & 78.0 & 74 & 47.2 \\
\hline Parapenaeus longirostris ${ }^{\dagger}$ & 6.8 & 11.0 & 53 & 33.8 \\
\hline Plesionika gigliolii ${ }^{\dagger}$ & 2.5 & 4.1 & 9 & 5.4 \\
\hline \multicolumn{5}{|l|}{ B. MSl } \\
\hline Plesionika gigliolii ${ }^{\dagger}$ & 66.3 & 28.4 & 163 & 19.8 \\
\hline Sergestes arcticus* & 50.1 & 21.4 & 8 & 1.0 \\
\hline Plesionika martia $^{\dagger}$ & 27.8 & 11.9 & 57 & 6.9 \\
\hline Plesionika edwardsii ${ }^{\dagger}$ & 23.3 & 10.0 & 104 & 12.7 \\
\hline Plesionika acanthonotus ${ }^{\dagger}$ & 16.9 & 7.2 & 28 & 3.5 \\
\hline Pasiphaea sivado* & 12.2 & 5.2 & 18 & 2.2 \\
\hline Nephrops norvegicus & 10.2 & 4.3 & 232 & 28.3 \\
\hline Aristeus antennatus $^{\dagger}$ & 10.1 & 4.3 & 114 & 13.9 \\
\hline Aristaeomorpha foliacea $^{\dagger}$ & 3.2 & 1.4 & 14 & 1.7 \\
\hline Solenocera membranacea & 2.8 & 1.2 & 6 & $<1.0$ \\
\hline \multicolumn{5}{|l|}{ C. MS2 } \\
\hline Plesionika martia ${ }^{\dagger}$ & 30.9 & 44.8 & 238 & 45.9 \\
\hline Aristeus antennatus $^{\dagger}$ & 15.3 & 22.2 & 125 & 24.2 \\
\hline Acanthephyra eximia ${ }^{\dagger}$ & 7.0 & 10.1 & 19 & 3.7 \\
\hline Plesionika acanthonotus ${ }^{\dagger}$ & 5.0 & 7.2 & 10 & 1.9 \\
\hline Sergia robusta* & 2.1 & 3.0 & 2 & $<1.0$ \\
\hline $\mathcal{N e m a t o c a r c i n u s ~ e x i l i s ~}^{\dagger}$ & 2.1 & 3.0 & 2 & $<1.0$ \\
\hline Munida tenuimana & 0.9 & 1.3 & 2 & $<1.0$ \\
\hline Polycheles typhlops & 0.9 & 1.2 & 7 & 1.3 \\
\hline Acanthephyra pelagica* & 0.9 & 1.2 & 4 & $<1.0$ \\
\hline Geryon longipes & 0.5 & 0.7 & 37 & 7.2 \\
\hline
\end{tabular}

*, mesopelagic species; ${ }^{\dagger}$, nektobenthic species. All other species are benthic.

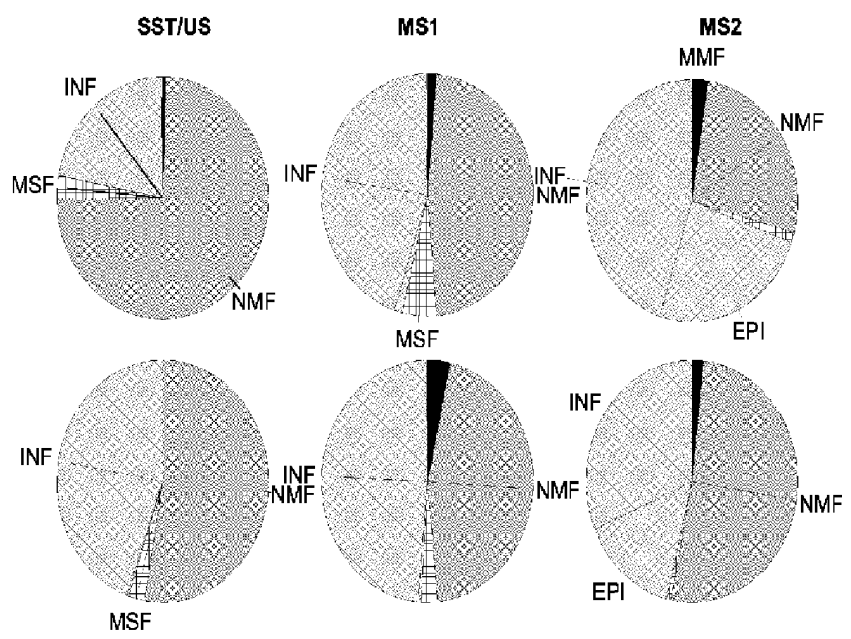

Figure 5. Relative biomass contribution of feeding guilds in each decapod crustacean assemblage for cruises Q1 (top) and Q2 (bottom). SST/US, shelf-slope transition/upper slope assemblage; MS1, middle slope assemblage; MS2, middle slope/lower slope assemblage. INF, infaunal feeders; MSF, macroplankton feeders scavengers; NMF, non-migrator macroplankton feeders; MMF, migrator macroplankton feeders; EPI, epifaunal feeders.

do exist, however, as to the contribution in abundance of each species. Fossorial species such as Nephrops norvegicus, Calocaris macandreae, or Alpheus glaber are more abundant in the Catalan Sea by an order of magnitude (cf. Cartes 
et al., 1994), probably due to a more suitable substrate for burrowing (terrigenous mud), while pagurid crabs (such as Pagurus excavatus or P. alatus) were absent in the present samplings. It also is informative to analyse the pattern of first appearances with depth of those species appearing

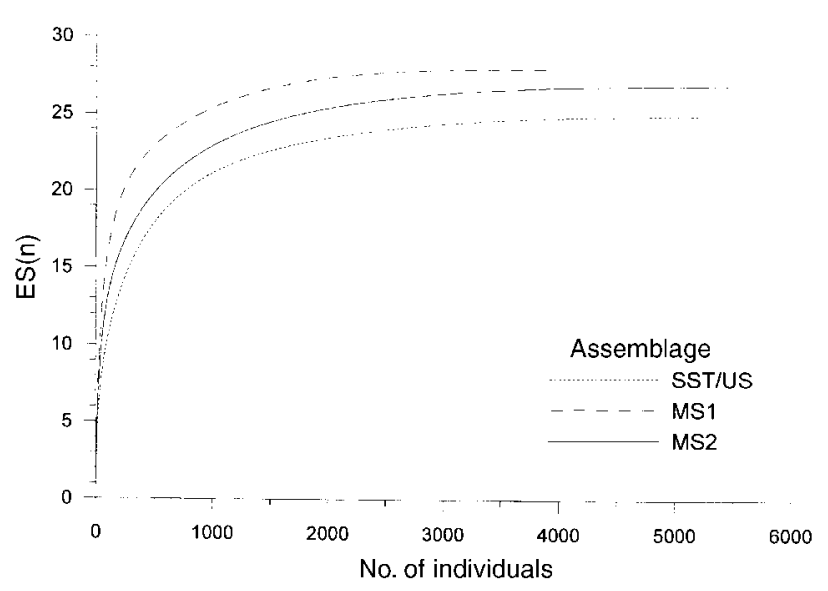

Figure 6. Cumulative species richness in the decapod crustacean assemblages detected in cruise Q1. only in the deeper assemblage (MS2), therefore inhabiting the most oligotrophic environment. When the recorded depth of first appearance is drawn across an imaginary west-east axis (Table 6; based on own data and published sources: Mura, 1987; Cartes et al., 1993; Pipitone \& Tumbiolo, 1993; Ungaro et al., 1999), most species (Acanthephyra pelagica, A. eximia, Nematocarcinus exilis, Paromola cuvieri and Stereomastis sculpta) first appear in very deep waters (around or below $1000 \mathrm{~m}$ ) in the Catalan Sea, while in Sardinia, the Sicilian Channel and the south Adriatic Sea they are first recorded well above $1000 \mathrm{~m}$. The depth of first appearance in the study area, to the south-west Balearic Islands is intermediate between the western and eastern extremes. A visual comparison of surface phytoplankton pigment concentration (PPC) for the Mediterranean Sea (available from NASA's SeaWiFS project image archive) showed that surface PPC for the Catalan Sea was between 0.5 and $1.0 \mathrm{mg} \mathrm{m}^{-3}$ at corresponding 200-2000 m depths, while surface PPC was much lower in the south-west Balearic Islands $\left(0.15-0.35 \mathrm{mg} \mathrm{m}^{-3}\right)$ and rarely exceeding $0.30 \mathrm{mg} \mathrm{m}^{-3}$ eastwards, towards Sardinia and Sicily. On the other hand, one species did not show this pattern (Pontophilus norvegicus), as its first record of appearance was deeper at the easternmost reported locality (Sicilian Channel). It is

Table 6. Depth of first appearance of deep-water decapod crustaceans at five well-sampled bathyal locations in the Mediterranean Sea, arranged from west to east.

\begin{tabular}{|c|c|c|c|c|c|}
\hline Species & Catalan Coast $^{\mathrm{a}}$ & Balearic Islands ${ }^{\mathrm{b}}$ & Sardinia $^{\mathrm{c}}$ & Sicilian Channel $^{\mathrm{d}}$ & South Adriatic ${ }^{e}$ \\
\hline Acanthephyra pelagica & 1008 & 626 & $480-510$ & NR & NR \\
\hline Acanthephyra eximia & 969 & 816 & NR & 733 & NR \\
\hline Nematocarcinus exilis & 1242 & 1094 & NR & NR & NR \\
\hline Paromola cuvieri & 662 & 626 & $350-400$ & 267 & $\sim 400$ \\
\hline Pontophilus norvegicus & 662 & 694 & $480-510$ & 704 & NR \\
\hline Stereomastis sculpta & 981 & 803 & NR & NR & NR \\
\hline
\end{tabular}

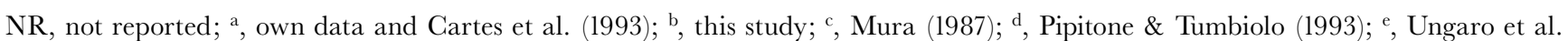
(1999).

Table 7. Relative contribution of decapod crustacean feeding guilds at two nearby areas in the western Mediterranean for the shelfslope transition/upper slope and the middle slope assemblages (abundance index: ind $10,000 \mathrm{~m}^{-2}$ ). See main text for a definition of feeding guilds. Data for the Catalan Sea recalculated from Cartes et al. (1994).

\begin{tabular}{|c|c|c|c|c|}
\hline & \multicolumn{2}{|c|}{ Catalan Sea } & \multicolumn{2}{|c|}{ South-west Balearic Islands } \\
\hline & Abundance & $\%$ & Abundance & $\%$ \\
\hline \multicolumn{5}{|l|}{ 1. SST/US } \\
\hline Deposit feeders & 12.6 & 3.5 & 1.2 & 1.0 \\
\hline Infaunal feeders & 22.4 & 6.4 & 11.0 & 9.5 \\
\hline Epifaunal feeders & 55.6 & 15.9 & 0.8 & 0.7 \\
\hline Macroplankton feeders / scavengers & 0.9 & 0.3 & 2.0 & 1.7 \\
\hline Non-migrator macroplankton feeders & 61.2 & 17.5 & 98.3 & 85.1 \\
\hline Migrator macroplankton feeders & 197.9 & 56.4 & 2.2 & 1.9 \\
\hline \multicolumn{5}{|l|}{ 2. MS1 } \\
\hline Deposit feeders & 27.2 & 1.7 & 2.7 & 1.5 \\
\hline Infaunal feeders & 65.3 & 40.7 & 23.9 & 13.5 \\
\hline Epifaunal feeders & 15.6 & 9.7 & 0.6 & 0.3 \\
\hline Makroplankton feeders / scavengers & 1.3 & 0.8 & 4.8 & 2.7 \\
\hline Non-migrator makroplankton feeders & 14.5 & 9.0 & 108.3 & 61.1 \\
\hline Migrator macroplankton feeders & 36.7 & 22.9 & 37.0 & 20.9 \\
\hline
\end{tabular}


perhaps remarkable that Pontophilus norvegicus is a temperate to subboreal species (for which the Mediterranean Sea is the southernmost limit of its distribution), while the other species are temperate to subtropical.

\section{Comparison with bathyal assemblages from the Catalan Sea}

The decapod crustacean biomass for the Catalan Sea (recalculated from Cartes et al., 1994) in autumn (corresponding to Q1) and spring (corresponding to Q2) were

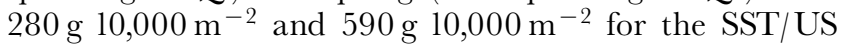

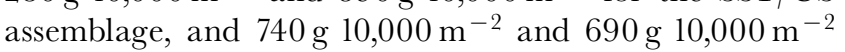
(MS1), respectively. Comparing these biomass values with our values reported in Table 3, the biomass of crustacean decapods for the two areas is shown to be very similar. However, the relative contribution of each species varies markedly between the two areas: nektobenthic species such as Plesionika spp. are more abundant in the southwest Balearic Islands than in the Catalan Sea, while infaunal (burrowing species) such as Alpheus glaber and Calocaris macandreae are up to ten times more abundant in the Catalan Sea bathyal assemblages (Cartes et al., 1994). These differences are perhaps best illustrated in a comparison of the relative contribution of each feeding guild to the total crustacean decapod abundance (Table 7). Migrator macroplankton-feeders $(\sim$ mesopelagic decapods) were dominant in the SST/US assemblage in the Catalan Sea $(56.4 \%$, Table 7$)$, and very important $(22.9 \%$; Table 7$)$ in the MS1 assemblage, while the dominant feeding guild in the south-west Balearic Islands was the non-migrator macroplankton-feeders (mainly pandalid shrimps) at the two depth assemblages $(85.1 \%$ in SST/US and 61.1\% in MS1). Migrator macroplankton played only a secondary role in the south-west Balearic Islands MSl assemblage (20.9\%; Table 7). It is also significant that both the relative and the absolute contributions of those feeding guilds closely related to bottom resources (i.e. epifaunal, infaunal and deposit-feeders) were more abundant in the Catalan Sea in both assemblages (Table 7).

\section{DISGUSSION}

It was found that decapod crustaceans are important or even dominant in number at mid-slope depths (400-800 m) when total megafaunal biomass is low. The local importance (in terms of abundance) of decapod crustaceans has been reported for the Catalan Sea (Cartes et al., 1994; Maynou et al., 1996), where they also form a sizeable fraction $(40-50 \%)$ of the total megafaunal biomass at upper slope and middle slope levels. Our results confirm the importance of decapod crustaceans in Mediterranean deep-sea benthic communities, perhaps because they are more competitive in oligotrophic environments, as opposed to the nearby Atlantic Ocean, where fish always dominate and where echinoderms constitute the major invertebrate group (Haedrich et al., 1980; Lampitt et al., 1986; Markle et al., 1988; Sardà et al., 1994).

The surface productivity regimes differ greatly between the Catalan Sea and the south-west Balearic Islands (yearly-averaged phytoplankton pigment concentrations of $0.5-1.0$ and $0.15-0.35 \mathrm{mg} \mathrm{m}^{-3}$, respectively) and this is indirectly reflected in the megafaunal assemblages studied here. On the other hand, advective inputs of organic carbon via submarine canyons are an additional input of food resources in the northern part of the Catalan Sea, (Buscail et al., 1990), and generally, organic C in the sediment surface is lower in interfluves or open sea areas, such as the south-west Balearic Islands. It is proposed that the relative importance of trophic guilds differs between the Catalan Sea and the south-west Balearic Islands, due to the differences in trophic web structure and energy flow. The most remarkable feature in the south-west Balearic Islands is the dominance of the non-migrator macroplankton feeding guild (mainly composed by pandalids of the genus Plesionika). The preferential exploitation of food of planktonic origin in an area with lower superficial primary production suggests a diminishing importance of benthos in the trophic webs of our study area, which is also supported by the low densities of deposit-feeders and infaunalfeeders when compared with the Catalan Sea (Table 7), where burrowing species such as Calocaris macandreae are an important food resource for crustacean decapods (Cartes \& Maynou, 1998).

The decapod crustacean taxocenoses described here were constituted by three clearly differentiated assemblages: a SST/US assemblage, down to $400 \mathrm{~m}$ depth, a shallow MS1 assemblage $(500-600 \mathrm{~m})$ and a deep MS2 assemblage (below $600 \mathrm{~m}$ ). These assemblages remained constant between seasons, coinciding with results in the Catalan Sea (Maynou et al., 1996). Depth has been repeatedly reported as the main factor affecting species distribution for benthic species (Abelló et al., 1988; Cartes et al., 1994; Day \& Pearcy, 1968; Haedrich et al., 1975, 1980; Wenner \& Boesch, 1979) and could be directly related to the first axis in our ordination. Likewise, the species diversity $(\mathrm{S})$ in each assemblage explained the second ordination axis and revealed a species-rich assemblage (MSl) contrasting with a species-poor assemblage (SST/US) and an assemblage with a strong species-richness gradient (MS2), where the disappearance of middle slope species and the appearance of new lower slope species takes place, such as Acanthephyra pelagica, A. eximia, Paromola cuvieri, Pontophilus norvegicus, Dorhynchus thomsoni, Stereomastis sculpta, Nematocarcinus exilis, Bathynectes maravigna and Hymenopenaeus debilis. Among macrofauna, maximum S has also been reported for mid-bathyal depths in a variety of taxa (e.g. gastropods; Rex, 1973). This phenomenon typically generates a bell-shaped response of species richness along depth or other environmentally mediated gradients (Gage \& Tyler, 1991). The intermediate disturbance hypothesis is often put forward to explain this pattern, as a mechanism combining varying-frequency disturbances and production/competition dynamics. The high disturbance of the continental shelf could explain the low species richness found in the SST/US assemblage, while the low species richness on the lower slope could be best explained by a decrease in food supply enhancing competitive exclusion and species exclusion (Gage \& Tyler, 1991). In our study area, the higher $\mathrm{S}$ at mid-bathyal depths coincided with an increase in the dominance by decapods, probably implying low trophic pressure or diminished competition with fish. 
Boundaries between assemblages (or communities) for megafauna vary among locations (Day \& Pearcy, 1968; Haedrich et al., 1975; Wenner \& Boesch, 1979; Haedrich et al., 1980; Markle et al., 1988; Cartes \& Sardà, 1993) and perhaps may be meaningfully compared only within regions (Hecker, 1990). In the Catalan Sea, Abelló et al. (1988) and Cartes et al. (1994) reported the boundary between the decapod crustacean assemblages corresponding to our SST/US/MSl at around 400-500 m, which is close to the boundary reported here (around $400 \mathrm{~m}$ ), while the boundary between the assemblages corresponding to MS1 and MS2 would be located below $600 \mathrm{~m}$ in the Catalan Sea (Cartes \& Sardà, 1993). However, this study failed to detect an important faunal discontinuity reported at $\sim 1200 \mathrm{~m}$ in the Catalan Sea (Cartes \& Sardà, 1992; Cartes, 1993) and in other Atlantic areas (Wenner \& Boesch, 1979; Hecker, 1990). This is probably related to the shallower depths occupied by the characteristic deep-water species (Acanthephyra spp., Nematocarcinus exilis and Stereomastis sculpta) in the southwest Balearic Islands than in the Catalan Sea (see also below). Another aspect pointed out by Cartes \& Sardà (1993) is the variability of boundary definitions among taxa. Comparing our results with a study on zonation of fish assemblages by Moranta et al. (1998), it can be seen that demersal fish in the northern Algerian Basin are mainly delimited by the $800 \mathrm{~m}$ depth contour, with further subassemblages in each group at depths differing from ours for decapod crustaceans. The different response shown by each taxon may be attributed to the distinct trophic levels occupied by different taxa: broadly speaking, fish and the various groups of invertebrates may exploit different fractions of the food resource or food spectrum and should show different response patterns to a depth gradient.

Although distinct assemblages can be discerned when analysing trawl haul data along a depth gradient by multivariate analysis, we agree with Haedrich \& Merrett (1990) in that their significance is strictly local and related to the taxocenosis studied. First, one does not uncover consistent or recurring boundaries when analysing invertebrate or vertebrate assemblages (compare Cartes \& Sardà (1993) with Stefanescu et al. (1992); Moranta et al. (1998) with the present work), i.e. the faunal discontinuities are not always sharp and they almost never coincide across animal taxa or geographic regions. The uniqueness of assemblage structure can best be explained by the combination of local environmental factors and the biogeographical history in the region considered. Thus although the actual species forming a local taxonomic assemblage is drawn (historically) from a regional pool of available species and linked by more or less well-defined ecological relationships, their observed abundances and relative proportions are best explained by the contemporary environmental conditions prevailing in the study area (Rickleffs, 1987). Clearly, the deep-water Mediterranean decapod crustaceans show the highest affinity with the immediate eastern Atlantic decapod fauna (Cartes, 1993), but it is poorer due to historical factors such as the Messinian salinity crisis (Pérès, 1985; Bouchet \& Taviani, 1992), the geographical barrier represented by the Gibraltar Strait and the current oligotrophic environment of the Mediterranean Sea.
Within an environmentally homogeneous area such as the deep Mediterranean, the composition of crustacean decapod assemblages scarcely varies (Abelló et al., 1988; Cartes et al., 1994; Pipitone \& Tumbiolo, 1993; Ungaro et al., 1999), but the depth at which typically bathyal species appear does vary. We found a trend of shallower first appearance of bathyal decapods towards the eastern Mediterranean, coinciding with increased oligotrophy (Table 6). The increased oligotrophy reported for the eastern Mediterranean is directly related to low surface primary productivity (phytoplankton pigment concentration differs almost by an order of magnitude between the west and the eastern Mediterranean). Other examples can be found linking primary productivity regimes and the structure of deep-sea macrobenthic and megabenthic communities at mid and large spatial scales (Watts et al., 1992).

This study was partly funded by the European Commission DG. XIV under contract no. FAIR CT-95-655.

\section{REFERENCES}

Abelló, P., Valladares, F.J. \& Castellón, A., 1988. Analysis of the structure of decapod crustacean assemblages off the Catalan coast (north-west Mediterranean). Marine Biology, 98, 39-49.

Bouchet, P. \& Taviani, M., 1992. The Mediterranean deep-sea fauna: pseudopopulations of Atlantic species? Deep-Sea Research, 39, 169-184.

Buscail, R., Pocklington, R., Daumas, R. \& Guidi, L., 1990. Fluxes and budget of organic matter in the benthic boundary layer over the northwestern Mediterranean margin. Continental Shelf Research, 10, 1089-1122.

Cartes, J.E., 1993. Deep-sea decapod fauna of the western Mediterranean: bathymetric distribution and biogeographic aspects. Crustaceana, 65, 29-40.

Cartes, J.E., 1998. Feeding strategies and partition of food resources in deep-water decapod crustaceans (between 400$2300 \mathrm{~m})$. Fournal of the Marine Biological Association of the United Kingdom, 78, 509-524.

Cartes, J.E., Abelló, P. \& Torres, P., 2000. The occurrence of Hymenopenaeus debilis S.I. Smith, 1882 (Decapoda: Aristeidae: Solenocerinae) in Mediterranean waters: a case of pseudopopulations from Atlantic origin? Fournal of the Marine Biological Association of the United Kingdom, in press.

Cartes, J.E., Company, J.B. \& Maynou, F., 1994. Deep-water decapod crustacean communities in the northwestern Mediterranean: influence of submarine canyons and season. Marine Biology, 120, 221-229.

Cartes, J.E. \& Maynou, F., 1998. Food consumption by bathyal decapod crustacean assemblages in the western Mediterranean: predatory impact of megafauna and the food consumption-food supply balance in a deep-water food web. Marine Ecology Progress Series, 171, 233-246.

Cartes, J.E. \& Sardà, F., 1992. Abundance and diversity of decapod crustaceans in the deep-Catalan Sea (western Mediterranean). Fournal of Natural History, 26, 1305-1323.

Cartes, J.E. \& Sardà, F., 1993. Zonation of deep-sea decapod fauna in the Catalan Sea (western Mediterranean). Marine Ecology Progress Series, 94, 27-34.

Cartes, J., Sardà, F. \& Abelló, P., 1993. Decapod crustaceans collected by deep-water trawls (between 1000 and $2200 \mathrm{~m}$ ) in the Catalan area (north-western Mediterranean). Bios (Thessaloniki). Scientific Annals of the School of Biology, 1, 207-213.

Day, D.S. \& Pearcy, W.G., 1968. Species associations of benthic fishes on the continental shelf and slope off Oregon. Fournal of the Fisheries Research Board of Canada, 25, 2665-2675. 
Dayton, P.K. \& Hessler, R.R., 1972. Role of biological disturbance in maintaining diversity in the deep sea. Deep-Sea Research, 19, 199-208.

Emelyanov, E.M., 1972. Principal types of recent bottom sediments in the Mediterranean Sea: their mineralogy and geochemistry. In The Mediterranean Sea: a natural sedimentation laboratory (ed. D.J. Stanley), pp.355-386. Stroudsburg: Dowden, Hutchinson \& Ross.

Fredj, G. \& Laubier, L., 1985. The deep Mediterranean benthos. In Mediterranean marine ecosystems (ed. M. MoraitouApostolopoulou and V. Kiortsis), pp.109-146. New York: Plenum Press.

Gage, J.D. \& Tyler, P.A., ed., 1991. Deep-sea biology. Cambridge: Cambridge University Press.

Haedrich, R.L. \& Merrett, N.R., 1990. Little evidence for faunal zonation or communities in deep sea demersal fish faunas. Progress in Oceanography, 24, 239-250.

Haedrich, R.L., Rowe, G.T. \& Polloni, P.T., 1975. Zonation of faunal composition of epibenthic population on the continental slope south of New England. Fournal of Marine Research, 33, 191-212.

Haedrich, R.L., Rowe, G.T. \& Polloni, P.T., 1980. The megabenthic fauna in the deep sea south of New England, USA. Marine Biology, 57, 165-179.

Hecker, B., 1990. Variation in megafaunal assemblages on the continental margin south of New England. Deep-Sea Research, 37, 37-57.

Hurlbert, S.H., 1971. The nonconcept of species diversity: a critique and alternative parameters. Ecology, 52, 577-586.

Lampitt, R.S., Billett, D.S.M. \& Rice, A.L., 1986. Biomass of the invertebrate megabenthos from 500 to $4100 \mathrm{~m}$ in the northeast Atlantic Ocean. Marine Biology, 93, 69-81.

Markle, D.F., Dadswell, M.J. \& Halliday, R.G., 1988. Demersal fish and decapod crustacean fauna of the upper continental slope off Nova Scotia from LaHave to St. Pierre Banks. Canadian Fournal of Zoology, 66, 1952-1960.

Maynou, F., Conan, G.Y., Cartes, J.E., Company, J.B. \& Sardà, F., 1996. Spatial structure and seasonality of decapod crustacean populations on the northwestern Mediterranean slope. Limnology and Oceanography, 41, 113-125.

Merrett, N.R. \& Haedrich, R.L., 1997. Deep-sea demersal fish and fisheries. London: Chapman \& Hall.

Merrett, N.R. \& Marshall, N.B., 1981. Observations on the ecology of deep-sea bottom living fishes collected off northwest Africa $\left(08^{\circ}-27^{\circ} \mathrm{N}\right)$. Progress in Oceanography, 9, $185-244$.

Moranta, J., Stefanescu, C., Massutí, E., Morales-Nin, B. \& Lloris, D., 1998. Fish community structure and depth-related trends on the continental slope of the Balearic Islands (Algerian Basin, western Mediterranean). Marine Ecology Progress Series, 171, 247-259.

Mura, M., 1987. Crostacei decapodi batiali della Sardegna meridionale. Rendiconti Seminario Facoltà Scienze Università Cagliari, 57, 189-199.
Paine, R.T., 1994. Excellence in ecology. Vol. 4. Marine rocky shores and community ecology: an experimentalist's perspective. Oldendorf/ Luhe, Germany: Ecology Institute.

Pérès, J.M., 1985. History of the Mediterranean biota and the colonization of the depths. In Key environments: western Mediterranean (ed. R. Margalef), pp.198-232. New York: Pergamon Press.

Pipitone, C. \& Tumbiolo, M.L., 1993. Decapod and stomatopod crustaceans from the trawlable bottoms of the Sicilian channel (central Mediterranean Sea). Crustaceana, 65, 358-364.

Rex, M.A., 1973. Deep-sea species diversity: decreased gastropod diversity at abyssal depths. Science, New York, 181, 1051-1053.

Rex, M.A., Stuart, G.T., Hessler, R.R., Allen, J.A., Sanders, H.L. \& Wilson, G.D.F., 1993. Global-scale latitudinal patterns of species diversity in the deep-sea benthos. Nature, London, 365, 636-639.

Rickleffs, R.E., 1987. Community diversity: relative roles of local and regional processes. Science, New York, 235, 167-171.

Rowe, G.T. \& Menzies, R.J., 1969. Zonation of large benthic invertebrates in the deep-sea off the Carolinas. Deep-Sea Research, 16, 531-537.

Sardà, F., Cartes, J.E. \& Company, J.B., 1994. Spatio-temporal variations in megabenthos abundance on three different habitats of the Catalan deep-sea (western Mediterranean). Marine Biology, 120, 211-220.

SeaWiFS Project. Available from: http://seawifs.gsfc.nasa.gov/ seawifs_scripts/med_subreg.pl.

Smith, C.R. \& Hamilton, S.C., 1983. Epibenthic megafauna of a bathyal basin off southern California: patterns of abundance, biomass, and dispersion. Deep-Sea Research, 30A, 907-928.

Sokolova, M.N., 1972. Trophic structure of deep-sea macrobenthos. Marine Biology, 16, 1-12.

Stefanescu, C., Lloris, D. \& Rucabado, J., 1992. Deep-living demersal fishes in the Catalan Sea (western Mediterranean) below a depth of $1000 \mathrm{~m}$. Fournal of Natural History, 26, 197-213.

Ungaro, N., Marano, C.A., Marsan, R., Martino, M., Marzano, M.C., Strippoli, G. \& Vlora, A., 1999. Analysis of demersal species assemblages from trawl surveys in the South Adriatic Sea. Aquatic Living Resources, 12, 177-185.

Watts, M.C., Etter, R.J. \& Rex, M.A., 1992. Effects of spatial and temporal scale on the relationship of surface pigments biomass to community structure in the deep-sea benthos. In Deep-sea food chains and the global carbon cycle (ed. G.T. Rowe and V. Pariente), pp. 245-254. Dordrecht: Kluwer Academic Publishers.

Wenner, E.L. \& Boesch, D.F., 1979. Distribution patterns of epibenthic decapod Crustacea along the shelf-slope coenocline, Middle Atlantic Bight, USA. Bulletin of the Biological Society of Washington, 3, 106-133.

Submitted 21 January 2000. Accepted 26 May 2000. 